\title{
GSP and Health Expenditure in Italian Regions
}

\author{
Cosimo Magazzino \\ Roma Tre University \\ Via G. Chiabrera 199, Rome (RM) 00145, Italy \\ Tel: 39-339-891-4072_E-mail: cmagazzino@uniroma3.it
}

Received: June 1, 2011

Accepted: July 27, 2011 Published: December 1, 2011

doi:10.5539/ijbm.v6n12p28

URL: http://dx.doi.org/10.5539/ijbm.v6n12p28

\begin{abstract}
This paper investigates the nexus between health care households' expenditure and GSP for Italian regions during 1980-2009, using time series and panel econometric techniques. After a brief introduction and a survey of the economic literature on this issue, we discuss the data and briefly introduce the methodologies. Empirical results show the presence of a long-run relationship in fifteen regions. As regards the causality analysis, health-led growth hypothesis is supported in three regions, while the reverse causation appears in five cases. The neutrality hypothesis seems to be confirmed in ten regions. Finally, a bi-directional causality flow (feedback hypothesis) has been found for two regions. Panel analysis shows that, if our sample is divided into three more homogeneous macro-regions (North, Centre and South), a long-run relationship between health expenditure and aggregate income has been found in two areas. Furthermore, the income elasticity is below the unity, implying that health expenditure is not a luxury good.
\end{abstract}

Keywords: Health policies, Households' expenditure, GSP, Stationarity, Cointegration, Causality, Italian regions

\section{Introduction}

The causal relationship between health care expenditure and economic growth has been a well-studied topic. Health is one of essential factors for any country's economic development and therefore plays an important role in economy activities.

Over the past three decades, a lot of studies - using the concepts of cointegration and Granger causality focused on several countries and time periods. Since the pioneering studies by Kleiman (1974), Newhouse (1977) and Cullis and West (1979), empirical findings are mixed and, for some countries, controversial (Devlin and Hansen, 2001). The results differ even on the direction of causality and the short-term versus long-term effects on health policies. Depending upon what kind of causal relationship exists, its policy implications may be significant.

Moreover, multiple causality studies have been done for many countries in the world; however, few studies have been devoted to the analysis of this nexus for the Italian case (Piperno and Di Orio, 1990; Devlin and Hansen, 2001; Giannoni and Hitiris, 2002; Erdil and Yetkiner, 2009).

This paper examines the nexus between the Gross State Product (GSP) and health care households' expenditure in the Italian regions for the period 1980-2009, using time series and panel methodologies on stationarity, cointegration and causality. The results might help to define and implement the appropriate health development policies in these regions. The data used are obtained by ISTAT.

The outline of this paper is as follows. Section 2 discusses the nexus between health care expenditure and GSP. In section 3 we illustrate the empirical methodology and the data; afterwards, we show and comment the empirical findings. The last section concludes with some interpretation of our main findings.

\section{The Relationship between Health Care Households' Expenditure and GSP}

Since $1960 \mathrm{~s}$ in most of the industrial economies, the share of health expenditure in GNP has been quite interesting to economic researchers (Word Bank, 2005). Several researches have reached a large consensus on the existence of a strong and positive correlation between health care expenditure and GSP, at the aggregate level.

The role of health expenditure on stimulating economic growth has been advocated by Mushkin (1962). This is also known as the health-led growth hypothesis. This hypothesis claims that health is a capital, thus investment on health can be used to stimulate overall economic growth (Grossman, 1972; Leu, 1986; Parkin et al., 1987; Hitiris 
and Posnett, 1992; Prichett and Summers, 1996), while other studies underlined the relevance of human capital accumulation process (Behrman, 1990; González Páramo, 1992; World Bank, 1993; Knowles and Owen, 1995; Currais and Rivera, 1997) as well as that of life expectancy (Barro and Sala-i-Martin, 1995).

Nevertheless, certain studies argued against these empirical findings (Newhouse, 1977).

The time series approach contributed to increase this literature, although stationarity analysis of the series reached controversial results (Hansen and King, 1996, 1998; Blomqvist and Carter, 1997; Roberts, 1999; McCoskey and Selden, 1998). These studies shaded light on the possibility that OLS estimates might be spurious, making conventional specifications of time series health care expenditure equations inadequate.

Some studies on the relationship between health spending and economic growth attempted to include other relevant variables such as health price and aging (Hitiris and Posnett, 1992; Hansen and King, 1996).

The impact of health expenditure on public finance is becoming a usual topic of recent comments and analysis. Textbook economic theory suggests that demand for a good/service by a utility-maximizing consumer depends on two factors: income and relative price. Most of the studies report an income elasticity exceeding unit, implying that health care is a luxury good. (In contrast, Wang (2009) found a cross-section income elasticity of health care around 0.7 , implying that health care is a necessity rather than a luxury good at the state level.)

Some recent works underline as the total mortality rates were pro-cyclical, showing the trade-off between unemployment rates and mortality rates. The main findings of these researches provided evidence that health improves during economic downturns (Ruhm, 2000, 2004; Laporte, 2004; Neumayer, 2004; Tapia Granados, 2005a, 2005b; Gerdtham and Ruhm, 2006).

On the contrary, Gerdtham and Johannesson (2003) found that recessions increase the mortality rate for men, but don't have any effect in relation to women. Yet, a concise introduction and overview to the applied economics of health is given by Taylor (2009).

\section{Econometric Methodology, Data and Discussion of Empirical Results}

Conventional regression techniques based on non-stationary time series produce spurious regression and statistics may simply indicate only correlated trends rather than a true relationship (Granger and Newbold, 1974). Spurious regression can be detected in regression model by low Durbin-Watson statistics and relatively moderate $R^{2}$.

When both series are integrated of the same order, we can proceed to test for the presence of cointegration. The Johansen maximum likelihood procedure (Johansen, 1988; Johansen and Juselius, 1990) is used for this purpose. Any long-run cointegrating relationship found between the series will contribute an additional error-correction term to the ECM.

Granger causality implies causality in the prediction (forecast) sense rather than in a structural sense. It starts with the premise that 'the future cannot cause the past'; if event A occurs after event B, then A cannot cause B (Granger, 1969). Therefore, in order to test whether health care households' expenditure Granger-causes GSP the following bivariate equation is estimated:

$$
\Delta y_{t}=\alpha_{0}+\sum_{i=1}^{m} \beta_{i} \Delta y_{t-i}+\sum_{j=1}^{n} \lambda_{i} \Delta e_{t-i}+v_{t}
$$

where $e_{t}=\ln \left(E_{t}\right) ; y_{t}=\ln \left(Y_{t}\right) ; E_{t}$ is the health care expenditure; $Y_{t}$ the real GSP per capita; and $\Delta$ is the first difference operator.

The presence of Granger-causality depends on the significance of the $\Delta e_{t-j}$ terms in eq. (1); health care expenditure causes GDP if the current value of $\Delta y$ is predicted better by including the past values of $\Delta e$ than by not doing so.

The short-run causality is based on a standard $F$-test statistics to test jointly the significance of the coefficients of the explanatory variable in their first differences. The long-run causality is based on a standard t-test. Negative and statistically significant values of the coefficients of the error correction terms indicate the existence of long-run causality.

For the purpose of this paper, the variables analyzed have been expressed in a logarithmic scale. Our empirical study uses annual data of real per capita GSP and real health care households' expenditure for the 1980-2009 period in the twenty Italian regions. The strongly balanced dataset has been obtained collecting the data from Health for All-Italy database - a geographic information system on sanity and health - by ISTAT (Note 1). The choice of the starting period was constrained by the availability of data on health care expenditure data.

The lag-order selection has been chosen according to the final prediction error (FPE), Akaike's information criterion (AIC), Schwarz's Bayesian information criterion (SBIC), and the Hannan and Quinn information criterion (HQIC) (Note 2). 
Cointegration tests have been subsequently applied, in order to be able to find the long-run relationship between GSP growth rate $(\triangle G S P)$ and health care expenditure variation $(\triangle H E)$. As is shown in Table 1, Johansen and Juselius cointegration method suggests that there is a cointegrating relationship in fifteen regions. In fact, the trace statistic and the maximum-eigenvalue statistic reject $r=0$ in favour of $r=1$ at the $5 \%$ critical value. As in the lag-length selection problem, choosing the number of cointegrating equations that minimizes either the SBIC or the HQIC provides a consistent estimator of the number of cointegrating equations. Yet, for Liguria we reach a controversial result, since the trace statistics suggests $r=1$, while the maximum-eigenvalue statistic $r=0$. Finally, for Basilicata cointegration tests reveals the presence of full rank $(r=2)$, which implies that our series are both stationary, or $I(0)$.

The cointegration analysis reveals that GSP and health care expenditure are particularly related in the central and southern regions, where more constraints to state public accounts are necessary, since the health care expenditure is out of control.

Granger causality tests suggest a bi-directional flow (with a feedback mechanism) for health care expenditure and GSP in two regions (Abruzzi and Trentino A.A.); in five cases aggregate income Granger-causes health expenditure (growth hypothesis); for Lombardy, Marches and Molise the causality flow runs from $H E$ to GSP; finally, the neutrality hypothesis (if no causality exists between our variables) is supported for the remaining ten regions. Therefore, the neutrality hypothesis seems to be the most case supported by our analyses. It's interesting to note that the growth hypothesis is prevailing in the Southern regions, where more expenditure cuts are advocated in order to reduce the state deficit as well as to control the regional budgets. In fact, in the last years, the central Government imposed a commissioner in several central and southern regions.

Moreover, a possible explanation of why, for ten regions, past and current health care expenditure and GSP values were insignificant to explain each other is given by Devlin and Hansen (2001). In fact, has to be acknowledged that the previous findings might not be robust to alternative specifications of causality tests (O'Connell, 1996; Blomqvist and Carter, 1997). Barros (1998) emphasized the relevance of institutional features of health systems, which may influence health care expenditures.

For the panel analysis, we have identified three macro-regions, which roughly represent different areas of the country according to income and geographical aspects: North, Centre and South (Note 3). The first step is to check for the integration properties of the variables involved. The null hypothesis of the Levin et al. (LLC, 2002) test is that each series in the panel contains a unit root $\left(H_{0}: \rho_{i}=1\right.$ for all $\left.i\right)$. The alternative hypothesis is that at least one of the individual series in the panel is stationary $\left(H_{0}: \rho_{i}<1\right)$. A major limitation of the LLC test is the assumption that all panels have the same value of $\rho$. Im et al. (IPS, 2003) use a $t$-bar statistic as the average of the individual ADF statistics which is normally distributed under the null hypothesis. Moreover, while the LLC test requires that the panels be strongly balanced, the IPS test doesn't, although there can be no gaps in each individual time series.

Table 2 shows the results of the panel unit root tests. The level models have been specified with fixed effects and country individual time trends in the data generating process. The time trends amount to fixed effects in the first difference specification. More or less, a unit root is detected for the level of GSP, while $H E$ seems to be non-stationary only for the Centre area. Yet, the first differences of the series appear to be stationary. Due to these results, each variable includes a random walk component. The panel cointegration tests point to the existence of a long-run relationship between health care households' expenditure and GSP.

In a panel setting, McCoskey and Selden (1998) rejected the null of non-stationarity for health care expenditure and income, implying that the former OLS results could be reinforced. But, they did not account for a time trend in their tests, which are based on the IPS approach. Allowing for linear trends, Gerdtham and Löthgren (2000) did not reject the null of a unit root for health care expenditures and GSP in a panel of OECD countries.

As for the panel cointegration tests, the $G a$ and $G t$ test statistics test $H_{0}: a_{i}=0$ for all $i$ versus $H_{l}: a_{i}<0$ for at least one $i$. While The $P a$ and $P t$ test statistics pool information over all the cross-sectional units to test $H_{0}: a_{i}=0$ for all $i$ against the alternative $a_{i}<0$ for all $i$. Here, the null of no cointegration is rejected by most of the Westerlund (2007) tests at the 5 percent level (Table 3). The group statistics shows how only for the South area we cannot reject the absence of panel cointegration. So, also panel data analysis reveals the long-run relationship between health care household expenditure and aggregate income.

Given the presence of cointegration in two sub-panels, the Dynamic OLS (DOLS) technique for heterogeneous cointegrated panels is estimated for these areas, to determine the long-run equilibrium relationship (Kao and Chiang, 2000). All the coefficients are statistically significant at the $1 \%$ level, and given the variables are expressed in natural logarithms, the coefficients can be interpreted as elasticities. For the North area, the results indicate that a $1 \%$ increase in per capita GSP decreases health care households' expenditure by $0.82 \%$. While, for the Centre, a $1 \%$ increase in per capita GSP increases health expenditure by 
$0.82 \%$. Here, it's quite interesting underline the different sign that GSP variable has got in the two cointegrating equations. The estimates of the income elasticities are substantially lower than that typically obtained in earlier works and are below one, as in Blomqvist and Carter (1997). Finally, since in both cases the income coefficient is smaller than unity, we can assert that health expenditure is a normal good rather than a luxury one.

\section{Conclusions}

In this paper, we used time series and panel methodologies to estimate the relationship between real health care households' expenditure and per capita aggregate income for twenty Italian regions during the years 1980-2009. Empirical results show the presence of a long-run relationship in fifteen regions. As regards the causality analysis, health-led growth hypothesis ( $\mathrm{HE} \rightarrow \mathrm{GSP}$ ) is supported in three regions, while the reverse causation (GSP $\rightarrow \mathrm{HE}$ ) appears in five cases. The neutrality hypothesis seems to be confirmed in ten regions. Finally, a bi-directional causality flow (feedback hypothesis) has been found for two regions. It's interesting to note that the growth hypothesis is prevailing in the Southern regions, where more expenditure cuts are advocated in order to reduce the state deficit as well as to control the regional budgets. In fact, in the last years, the central Government imposed a commissioner in several central and southern regions.

Panel analyses show that, if our sample is divided into three more homogeneous macro-regions (North, Centre and South), a long-run relationship between health expenditure and aggregate income has been found in two of these areas. The long-run elasticity estimates are statistically significant, with the magnitude of the estimates very similar across both panel datasets. Yet, in the northern regions panel the sign of GSP is negative, while for the central region it is positive. A possible explanation of this could be that in the North, where the richness is widespread and the per capita income is sensibly higher than that of other areas, an additional increase of private income might provoke the translation of the demand for health from public to private suppliers, reducing the health care expenditure of those regions ("opting out" effect).

One main finding of this paper is that a cointegration relationship between health care households' expenditure and GSP, both in real values, has been found, as in Gerdtham and Löthgren (2000), Dreger and Reimers (2005), and Chakroun (2009); while they are quite different to that of in Hansen and King (1996) and Bukenya (2009), according to which, after detecting unit roots in the data, a long-run relationship seemed to exist only in few cases.

Moreover, in contrast to many previous studies, we show that the income elasticity of health care expenditure is below unity. Thus, health expenditure seems to be not a luxury good in the Italian regional case.

Finally, it is relevant to underline that reducing health care expenditures would contribute to improve the Italian public finance scenario, with low public deficit and debt/GDP ratios.

\section{Future Research}

Further analysis may be conducted studying the nexus between different items of health care expenditure and aggregate income in Italy.

\section{References}

Barro, R. J., \& Sala-i-Martin, X. (1995). Economic Growth. Princeton: McGraw-Hill.

Barros, P. P. (1998). The black box of health care expenditure growth determinants. Health Economics, 7 , 533-544. http://dx.doi.org/10.1002/(SICI)1099-1050(199809)7:6<533::AID-HEC374>3.0.CO;2-B

Behrman, J. R. (1990). The action of human resources and poverty on one another. That we have yet to learn. World Bank Living Standards Measurement Working Paper, 74.

Blomqvist, A. G., \& Carter, R. A. L. (1997). Is health care really a luxury?. Journal of Health Economics, 16(2), 207-229. http://dx.doi.org/10.1016/S0167-6296(96)00534-6

Bukenya, J. (2009). Do Fluctuations in Health Expenditure Affect Economic Growth?. The Open Economics Journal, 2, 31-38.

Chakroun, M. (2009). Health care expenditure and GDP: An international panel smooth transition approach. MPRA Paper, 17559.

Cullis, J. G., \& West, P. A. (1979). The economics of health: An introduction. Oxford: Martin Robertson.

Currais, L., \& Rivera, B. (1997). Human capital and growth: Does health affect productivity?. La Coruna University Working Paper.

Devlin, N., \& Hansen, P. (2001). Health care spending and economic output: Granger causality. Applied Economics Letters, 8(8), 561-564. http://dx.doi.org/10.1080/13504850010017357 
Dreger, C., \& Reimers, H. E. (2005). Health care expenditures in OECD countries: a panel unit root and cointegration analysis. International Journal of Applied Econometrics and Quantitative Studies, 2, 2, 5-20.

Erdil, E., \& Yetkiner, I. H. (2009). The Granger-causality between health care expenditure and output: a panel data approach. Applied Economics, 41, 4, 511-518. http://dx.doi.org/10.1080/00036840601019083

Gerdtham, U.-G., \& Johannesson, M. (2003). A Note on the Effect of Unemployment on Mortality. Journal of Health Economics, 22(3), 505-518. http://dx.doi.org/10.1016/S0167-6296(03)00004-3

Gerdtham, U.-G., \& Löthgren, M. (2000). On stationary and cointegration of international health expenditure and GDP. Journal of Health Economics, 19(4), 461-475. http://dx.doi.org/10.1016/S0167-6296(99)00036-3

Gerdtham, U.-G., \& Ruhm, C. J. (2006). Deaths rise in good economic times: Evidence from the OECD. Economics and Human Biology, 4(3), 298-316. http://dx.doi.org/10.1016/j.ehb.2006.04.001

Giannoni, M., \& Hitiris, T. (2002). The regional impact of health care expenditure: the case of Italy. Applied Economics, 34, 1829-1836. http://dx.doi.org/10.1080/00036840210126809

González Páramo, J. J. (1992). Sanidad desarrollo y crecimiento económico. Análisis Económico de la Sanidad.

Granger, C. W. J. (1969). Investigating causal relations by econometric models and cross-spectral methods. Econometrica, 37, 424-438. http://dx.doi.org/10.2307/1912791

Granger, C. W. J., \& Newbold, P. (1974). Spurious regression in econometrics. Journal of Econometrics, 2(2), 111-120. http://dx.doi.org/10.1016/0304-4076(74)90034-7

Grossman, M. (1972). On the concept of health capital and the demand for health. Journal of Political Economy, 80(2), 223-255. http://dx.doi.org/10.1086/259880

Hansen, P., \& King, A. (1996). The determinants of health care expenditure: A cointegration approach. Journal of Health Economics, 17, 377-381. http://dx.doi.org/10.1016/S0167-6296(98)00028-9

Hansen, P., \& King, A. (1998). Health care expenditure and GDP: panel data unit root test results - comment. Journal of Health Economics, 15(1), 127-137. http://dx.doi.org/10.1016/0167-6296(95)00017-8

Hitiris, T., \& Posnett, J. (1992). The determinants and effects of health expenditure in developed countries. Journal of Health Economics, 11(2), 173-181. http://dx.doi.org/10.1016/0167-6296(92)90033-W

Im, K. S., Pesaran, M. H., \& Shin, Y. (2003). Testing for unit roots in heterogeneous panels. Journal of Econometrics, 115, 53-74. http://dx.doi.org/10.1016/S0304-4076(03)00092-7

Johansen, S. (1988). Statistical analysis of cointegrating vector. Journal of Economic Dynamics and Control, 12(2-3), 231-255. http://dx.doi.org/10.1016/0165-1889(88)90041-3

Johansen, S., \& Juselius, K. (1990). Maximum likelihood estimation and inference on cointegration with applications to the demand for money. Oxford Bulletin of Economics and Statistics, 52(2), 169-210. http://dx.doi.org/10.1111/j.1468-0084.1990.mp52002003.x

Kao, C., \& Chiang, M. H. (2000). On the estimation and inference of a cointegrated regression in panel data. Advances in Econometrics, 15, 179-222. http://dx.doi.org/10.1016/S0731-9053(00)15007-8

Kleiman, E. (1974). The determinants of national outlay on health. In Perlman, M. (ed.). The economics of health and medical care. London: Macmillan, 66-81.

Knowles, S., \& Owen, P. D. (1995). Health capital and cross-country variation in income per capita in the Mankiw-Romer-Weil model. Economic Letters, 48, 99-106. http://dx.doi.org/10.1016/0165-1765(94)00577-O

Laporte, A. (2004). Do Economic Cycles Have a Permanent Effect on Population Health? Revisiting the Brenner Hypothesis. Health Economics, 13(8), 767-779. http://dx.doi.org/10.1002/hec.854

Leu, R. R. (1986). The public-private mix and international health care cost. In Culyer, A. J., Jönsson, B. (eds.). Public and private health services: Complementarities and conflicts. Oxford: Basil Blackwell.

Levin, A., Lin, C.-F., \& Chu, C.-S. J. (2002). Unit root tests in panel data: Asymptotic and finite-sample properties. Journal of Econometrics, 108, 1-24. http://dx.doi.org/10.1016/S0304-4076(01)00098-7

Magazzino, C., \& Mele, M. (2011). Health Care Expenditure and Economic Growth in Southern Italian Regions: an Empirical Analysis. Rassegna Economica.

McCoskey, S. K., \& Selden, T. M. (1998). Health care expenditures and GDP: panel data unit root test results. Journal of Health Economics, 17 (3), 369-376. http://dx.doi.org/10.1016/S0167-6296(97)00040-4

Mushkin, S. J. (1962). Health as an investment. Journal of Political Economy, 70(5), 129-157. http://dx.doi.org/10.1086/258730 
Neumayer, E. (2004). Recessions Lower (Some) Mortality Rates. Social Science \& Medicine, 58(6), 1037-1047. http://dx.doi.org/10.1016/S0277-9536(03)00276-4

Newhouse, J. P. (1977). Medical are expenditure: A cross-national survey. Journal of Human Resources, 12, 115-125. http://dx.doi.org/10.2307/145602

O'Connell, J. (1996). The relationship between health expenditures and the age structures of the population in OECD countries. Health Economics, 573-578. http://dx.doi.org/10.1002/(SICI)1099-1050(199611)5:6<573::AID-HEC231>3.0.CO;2-L

Parkin, D., McGuire, A., \& Yule, B. (1987). Aggregate health care expenditures and national income: Is health care a luxury goods?. Journal of Health Economics, 6(2), 109-127. http://dx.doi.org/10.1016/0167-6296(87)90002-6

Piperno, A., \& Di Orio, F. (1990). Social Differences in Health and Utilization of Health Services in Italy. Social Science and Medicine, 31, 305-312. http://dx.doi.org/10.1016/0277-9536(90)90277-Y

Pritchett, L., \& Summers, L. H. (1996). Wealthier is healthier. Journal of Human Resources, 31, 841-868. http://dx.doi.org/10.2307/146149

Rivera, B., \& Currais, L. (1999). Economic growth and health: direct impact or reverse causation?. Applied Economics Letters, 6, 11, 761-764. http://dx.doi.org/10.1080/135048599352367

Roberts, A. A. (1999). The labour market consequences of family illness. Journal of Mental Health Policy and Economics, 2, 183-195. http://dx.doi.org/10.1002/(SICI)1099-176X(199912)2:4<183::AID-MHP62>3.0.CO;2-1

Ruhm, C. J. (2000). Are Recessions Good For Your Health?. Quarterly Journal of Economics, 115(2), 617-650. http://dx.doi.org/10.1162/003355300554872

Ruhm, C. J. (2004). Maternal Employment and Adolescent Development. National Bureau of Economic Research Working Paper, 10691.

Tapia Granados, J. (2005a). Increasing Mortality during the Expansions of the U.S. Economy, 1900-1996. International Journal of Epidemiology, 34(6), 1194-1202. http://dx.doi.org/10.1093/ije/dyi141

Tapia Granados, J. (2005b). Recessions and Mortality in Spain, 1980-1997. European Journal of Population, 21(4), 393-422. http://dx.doi.org/10.1007/s10680-005-4767-9

Taylor, M. P. (2009). The applied economics of health: introduction and overview. Applied Economics, 41, 413-415. http://dx.doi.org/10.1080/00036840902757241

Wagstaff, A. (1986). The demand for health: some new empirical evidence. Journal of Health Economics, 5, 195-233. http://dx.doi.org/10.1016/0167-6296(86)90015-9

Wang, Z. (2009). The determinants of health expenditures: evidence from US state-level data. Applied Economics, 41(4), 429-435. http://dx.doi.org/10.1080/00036840701704527

Westerlund, J. (2007). Testing for error correction in panel data. Oxford Bulletin of Economics and Statistics, 69, 709-748. http://dx.doi.org/10.1111/j.1468-0084.2007.00477.x

World Bank. (1993). World Development Report 1993. Washington: World Bank Press.

World Bank. (2005). World Development Report 2005. Washington: World Bank Press.

\section{Notes}

Note 1. See, for more details: http://www.istat.it/dati/db_siti/.

Note 2. The correlation coefficients and unit root tests are available upon request.

Note 3. North: Piedmont, Vallée d'Aoste, Lombardy, Trentino Alto Adige, Veneto, Friuli Venezia Giulia and Liguria. Centre: Emilia Romagna, Tuscany, Umbria, Marches, Latium and Abruzzi. South: Molise, Campania, Puglia, Basilicata, Calabria, Sicily and Sardinia. 
Table 1. Results for Granger causality and cointegration tests

\begin{tabular}{|c|c|c|c|c|c|c|c|}
\hline Region & $\begin{array}{l}\text { Granger } \\
\text { causality }\end{array}$ & Lags & $\chi^{2}$-statistic & P-Value & $\begin{array}{c}\text { Trace } \\
\text { statistic }\end{array}$ & $\begin{array}{c}\text { Maximum } \\
\text { eigenvalue } \\
\text { statistic }\end{array}$ & Rank \\
\hline \multirow[t]{2}{*}{ Piedmont } & $\mathrm{GSP} \rightarrow \mathrm{HE}$ & 1 & 0.149 & 0.700 & 18.6669 & 14.0314 & \multirow[t]{2}{*}{0} \\
\hline & $\mathrm{HE} \rightarrow \mathrm{GSP}$ & 1 & 0.001 & 0.971 & (19.96) & $(15.67)$ & \\
\hline Vallée & $\mathrm{GSP} \rightarrow \mathrm{HE}$ & 1 & 0.052 & 0.819 & 21.5265 & 14.9375 & \multirow[t]{2}{*}{0} \\
\hline d'Aoste & $\mathrm{HE} \rightarrow \mathrm{GSP}$ & 1 & 0.180 & 0.672 & $(25.32)$ & (18.96) & \\
\hline \multirow[t]{2}{*}{ Lombardy } & $\mathrm{GSP} \rightarrow \mathrm{HE}$ & 1 & 1.813 & 0.178 & 4.2651 & 4.2651 & \multirow[t]{2}{*}{1} \\
\hline & $\mathrm{HE} \rightarrow \mathrm{GSP}$ & 1 & 3.885 & $0.049 * *$ & $(9.42)$ & $(9.24)$ & \\
\hline \multirow[t]{2}{*}{ T.A.A. } & $\mathrm{GSP} \rightarrow \mathrm{HE}$ & 3 & 10.289 & $0.016 * *$ & 7.4578 & 7.4578 & \multirow[t]{2}{*}{1} \\
\hline & $\mathrm{HE} \rightarrow \mathrm{GSP}$ & 3 & 6.8438 & $0.077 *$ & $(12.25)$ & $(12.52)$ & \\
\hline \multirow[t]{2}{*}{ Veneto } & $\mathrm{GSP} \rightarrow \mathrm{HE}$ & 2 & 3.161 & 0.206 & 5.6771 & 5.6771 & \multirow[t]{2}{*}{1} \\
\hline & $\mathrm{HE} \rightarrow \mathrm{GSP}$ & 2 & 1.323 & 0.516 & $(9.42)$ & $(9.24)$ & \\
\hline \multirow[t]{2}{*}{ F.V.G. } & $\mathrm{GSP} \rightarrow \mathrm{HE}$ & 1 & 1.778 & 0.182 & 19.9141 & 15.4978 & \multirow[t]{2}{*}{0} \\
\hline & $\mathrm{HE} \rightarrow \mathrm{GSP}$ & 1 & 0.648 & 0.421 & (19.96) & $(15.67)$ & \\
\hline \multirow[t]{2}{*}{ Liguria } & $\mathrm{GSP} \rightarrow \mathrm{HE}$ & 1 & 0.044 & 0.567 & 20.1770 & 14.9903 & \multirow[t]{2}{*}{1} \\
\hline & $\mathrm{HE} \rightarrow \mathrm{GSP}$ & 1 & 0.030 & 0.833 & $(19.96)$ & $(15.67)$ & \\
\hline Emilia & $\mathrm{GSP} \rightarrow \mathrm{HE}$ & 3 & 51.432 & $0.000 * * *$ & 7.4938 & 7.4938 & 1 \\
\hline Romagna & $\mathrm{HE} \rightarrow \mathrm{GSP}$ & 3 & 2.685 & 0.443 & $(12.25)$ & $(12.52)$ & \\
\hline \multirow[t]{2}{*}{ Tuscany } & $\mathrm{GSP} \rightarrow \mathrm{HE}$ & 1 & 1.293 & 0.256 & 3.9656 & 3.9656 & \multirow[t]{2}{*}{1} \\
\hline & $\mathrm{HE} \rightarrow \mathrm{GSP}$ & 1 & 0.499 & 0.480 & $(9.42)$ & $(9.24)$ & \\
\hline \multirow[t]{2}{*}{ Umbria } & $\mathrm{GSP} \rightarrow \mathrm{HE}$ & 1 & 0.009 & 0.923 & 5.9495 & 5.9495 & \multirow[t]{2}{*}{1} \\
\hline & $\mathrm{HE} \rightarrow \mathrm{GSP}$ & 1 & 1.258 & 0.262 & $(9.42)$ & $(9.24)$ & \\
\hline \multirow[t]{2}{*}{ Marches } & $\mathrm{GSP} \rightarrow \mathrm{HE}$ & 3 & 5.559 & 0.135 & 17.6986 & 14.8729 & \multirow[t]{2}{*}{1} \\
\hline & $\mathrm{HE} \rightarrow \mathrm{GSP}$ & 3 & 15.641 & $0.001 * * *$ & (19.96) & $(15.67)$ & \\
\hline \multirow[t]{2}{*}{ Latium } & $\mathrm{GSP} \rightarrow \mathrm{HE}$ & 1 & 4.589 & $0.032 * *$ & 7.4863 & 7.4863 & \multirow[t]{2}{*}{1} \\
\hline & $\mathrm{HE} \rightarrow \mathrm{GSP}$ & 1 & 4.159 & 0.041 & $(12.25)$ & $(12.52)$ & \\
\hline \multirow[t]{2}{*}{ Abruzzi } & $\mathrm{GSP} \rightarrow \mathrm{HE}$ & 4 & 10.092 & $0.039 * *$ & 22.7790 & 14.8302 & \multirow[t]{2}{*}{0} \\
\hline & $\mathrm{HE} \rightarrow \mathrm{GSP}$ & 4 & 27.056 & $0.000 * * *$ & $(25.32)$ & $(18.96)$ & \\
\hline \multirow[t]{2}{*}{ Molise } & $\mathrm{GSP} \rightarrow \mathrm{HE}$ & 2 & 3.558 & 0.169 & 7.2379 & 7.2379 & \multirow[t]{2}{*}{1} \\
\hline & $\mathrm{HE} \rightarrow \mathrm{GSP}$ & 2 & 11.229 & $0.004 * * *$ & $(9.42)$ & $(9.24)$ & \\
\hline Campania & $\mathrm{GSP} \rightarrow \mathrm{HE}$ & 2 & 0.019 & 0.991 & 7.8048 & 7.8048 & 1 \\
\hline & $\mathrm{HE} \rightarrow \mathrm{GSP}$ & 2 & 3.005 & 0.223 & $(12.25)$ & $(12.52)$ & \\
\hline Puglia & $\mathrm{GSP} \rightarrow \mathrm{HE}$ & 1 & 1.600 & 0.206 & 2.1240 & 2.1240 & 1 \\
\hline & $\mathrm{HE} \rightarrow \mathrm{GSP}$ & 1 & 0.006 & 0.939 & $(9.42)$ & $(9.24)$ & \\
\hline Basilicata & $\mathrm{GSP} \rightarrow \mathrm{HE}$ & 2 & 12.735 & $0.002 * * *$ & 16.9138 & 16.9138 & 2 \\
\hline & $\mathrm{HE} \rightarrow \mathrm{GSP}$ & 2 & 1.562 & 0.458 & $(12.25)$ & $(12.52)$ & \\
\hline Calabria & $\mathrm{GSP} \rightarrow \mathrm{HE}$ & 2 & 6.209 & $0.045 * *$ & 1.2599 & 1.2599 & 1 \\
\hline & $\mathrm{HE} \rightarrow \mathrm{GSP}$ & 2 & 2.126 & 0.345 & $(9.42)$ & $(9.24)$ & \\
\hline Sicily & $\mathrm{GSP} \rightarrow \mathrm{HE}$ & 2 & 1.003 & 0.606 & 22.5025 & 16.9835 & 0 \\
\hline & $\mathrm{HE} \rightarrow \mathrm{GSP}$ & 2 & 3.782 & 0.151 & $(25.32)$ & $(18.96)$ & \\
\hline Sardinia & $\mathrm{GSP} \rightarrow \mathrm{HE}$ & 2 & 10.137 & $0.006^{* * *}$ & 2.3713 & 2.3713 & 1 \\
\hline & $\mathrm{HE} \rightarrow \mathrm{GSP}$ & 2 & 1.292 & 0.524 & $(9.42)$ & $(9.24)$ & \\
\hline
\end{tabular}

Notes: 5\% Critical Values in parenthesis. 
Table 2. Panel unit root tests

\begin{tabular}{|c|c|c|c|c|}
\hline \multicolumn{5}{|c|}{ Im, Pesaran and Shin (IPS) test } \\
\hline Region & GSP & $\Delta G S P$ & HE & $\Delta \mathrm{HE}$ \\
\hline North & $\begin{array}{c}-1.0961 \\
(0.1365)\end{array}$ & $\begin{array}{r}-10.3577 \\
(0.0000)\end{array}$ & $\begin{array}{l}-3.1679 \\
(0.0008)\end{array}$ & $\begin{array}{r}-11.0222 \\
(0.0000)\end{array}$ \\
\hline Centre & $\begin{array}{c}-1.1453 \\
(0.1260)\end{array}$ & $\begin{array}{l}-9.5259 \\
(0.0000)\end{array}$ & $\begin{array}{l}-1.8100 \\
(0.0351)\end{array}$ & $\begin{array}{l}-8.8688 \\
(0.0000)\end{array}$ \\
\hline South & $\begin{array}{c}-0.4282 \\
(0.3343)\end{array}$ & $\begin{array}{r}-12.6503 \\
(0.0000)\end{array}$ & $\begin{array}{l}-3.4259 \\
(0.0003)\end{array}$ & $\begin{array}{r}-10.0143 \\
(0.0000)\end{array}$ \\
\hline \multicolumn{5}{|c|}{ Levin, Lin and Chu (LLC) test } \\
\hline North & $\begin{array}{l}-1.7305 \\
(0.0418)\end{array}$ & $\begin{array}{r}-10.6162 \\
(0.0000)\end{array}$ & $\begin{array}{l}-3.0082 \\
(0.0013)\end{array}$ & $\begin{array}{r}-11.0222 \\
(0.0000)\end{array}$ \\
\hline Centre & $\begin{array}{l}-1.8050 \\
(0.0335)\end{array}$ & $\begin{array}{r}-10.0975 \\
(0.0000)\end{array}$ & $\begin{array}{l}-1.8311 \\
(0.0335)\end{array}$ & $\begin{array}{l}-8.4999 \\
(0.0000)\end{array}$ \\
\hline South & $\begin{array}{l}-1.7608 \\
(0.0391)\end{array}$ & $\begin{array}{r}-13.4711 \\
(0.0000)\end{array}$ & $\begin{array}{l}-2.5942 \\
(0.0047)\end{array}$ & $\begin{array}{l}-8.8198 \\
(0.0000)\end{array}$ \\
\hline
\end{tabular}

Notes: Critical value at the 5\% significance level in parenthesis. Panel unit root test includes intercept and trend.

Table 3. Panel cointegration tests (Westerlund)

\begin{tabular}{|l|c|c|c|}
\hline Region & $\begin{array}{c}\text { Group statistics } \\
\text { and Panel statistics }\end{array}$ & Value & P-Value \\
\hline North & Gt & -3.253 & 0.000 \\
& Pt & -5.755 & 0.034 \\
\hline Centre & Gt & -4.539 & 0.000 \\
& Pt & -4.909 & 0.100 \\
\hline South & Gt & -1.442 & 0.852 \\
& Pt & -4.375 & 0.320 \\
\hline
\end{tabular}

Notes: Critical value at the 5\% significance level in parenthesis. Panel cointegration test includes intercept.

Table 4. DOLS long-run estimates

\begin{tabular}{|c|c|}
\hline Region & Cointegrating equation \\
\hline North & $\mathrm{HE}=0.5581-0.8241 \mathrm{GSP}$ \\
& $(10.62) \quad(-15.68)$ \\
& $R^{2}=0.7364 ;$ Wald- $\chi^{2}=245.85$ \\
\hline Centre & $\mathrm{HE}=0.6397+0.8204 \mathrm{GSP}$ \\
& $(15.92) \quad(20.42)$ \\
& $R^{2}=0.4288 ;$ Wald $-\chi^{2}=9038.65$ \\
\hline
\end{tabular}

Notes: $t$-statistics in parenthesis. 